\title{
NATIVE CHARACTERISTIC OF INDIGENOUS INDONESIAN CULTURE AS REFERENCE IN RE- DESIGNING TOURISM AREA
}

\author{
Wawan Ardiyan Suryawan*, Ainiyah Intan Permatasari* \\ *) Department of Architecture, FADP ITS, Surabaya 60111, Indonesia \\ e-mail: wawanardyan.arch@gmail.com
}

\begin{abstract}
Mount Bromo has been well known nationally and even internationally has stunning natural beauty and unique culture of its inhabitants. Both of these have proved able to attract many local and foreign tourists to visit, so its impact also could be felt directly on the economy improvement of local communities and also for the state's foreign exchange from the tourism sector. The uniqueness of Tengger culture can be regarded as a national treasure that has been maintained by the Government sustainably. An idea that is proposed as an effort to help its preservation is to adopt the concept of Ubud Culture Village in Bali. It is considered the most suitable to be applied because it will not only absorb tourists, but also maintain the authenticity of local culture, especially the function and architectural form of traditional buildings of the Tengger tribe that must also be preserved.
\end{abstract}

Keywords: culture, economy, preservation

\section{INTRODUCTION}

According to Koentjaraningrat (Koentjaraningrat, 1974), the form of culture is divided into three elements, namely: (1) Culture in the form of ideas, thought, values, norms, and regulations. For examples: customs, rules and manners in society. (2) Culture in the form of activity of human behavior in society. For examples: the pattern of mutual cooperation life and ceremonies. (3) Culture in the form of objects of human works. For examples: palaces, mosques, temples, weapons, buildings, and fortresses.

One example of culture activity which is almost extinct is a traditional ceremony conducted by Tenggerese. They run many traditional ceremonies, such as the Kasada ceremony, the Karo ceremony, the Unan-unan ceremony, the Kapat, Kawulu and Kasanga ceremonies, Mayu Banyu and Mayu Desa ceremonies, and much more. Among those ceremonies, Kasada ceremony is the greatest ceremony. 
In addition to its large, Kasada ceremony is also closely related to the origin of the Tengger tribe living in the vicinity of Mount Bromo, so only the Tenggerese who carry out the Kasada ceremony (Figure 1).

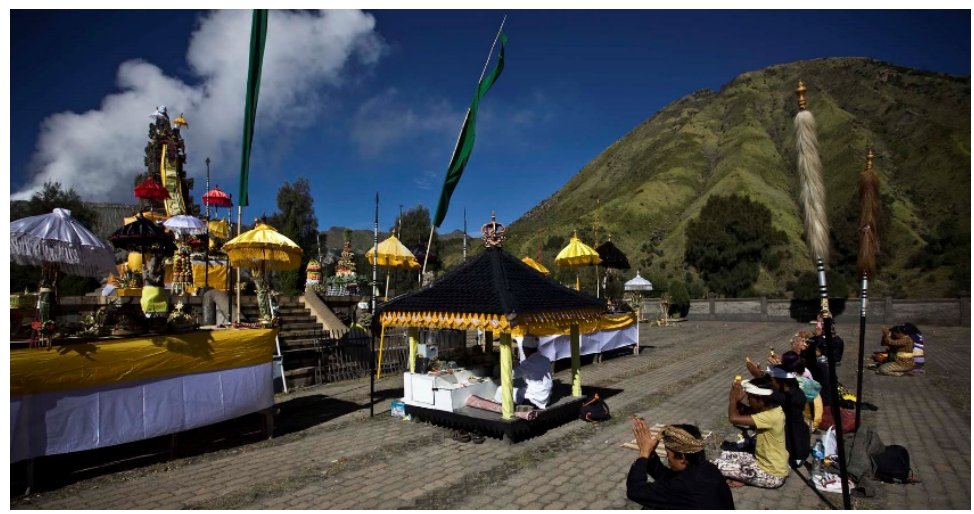

Figure 1. Kasada Ceremony

Source: destinasi-indonesia.com

Culture done by Tengger tribe itself can be said almost extinct because of its existence which is only carried out by Tengger tribe who lives in the hinterland around Mount Bromo and Mount Semeru. Historically, Tengger tribe comes from the kingdom of Majapahit. At that time the Majapahit kingdom suffered a setback. In 1364 Gajah Mada died. However, Majapahit under the rule of Hayam Wuruk managed to maintain its glory until he died in 1389. Majapahit power was then ruled by Wikramawardana, son-in-law of Hayam Wuruk. Since then Majapahit suffered a setback (Al Anshori, 2010).

The event of the retreat of the Majapahit kingdom coincided with the widespread spreading of Islam in Java. It is estimated that Islam entered Java Island in the late fourteenth century or early fifteenth century. This can be proved by the inscription on the gravestone of Maulana Malik Ibrahim who died in 1419 AD, after the fall of the Hindu Majapahit kingdom (Turmudi, 2008).

At that time, the kingdom of Majapahit experienced a mismatch with the existing Islamic kingdom on the island of Java so that the kingdom of Majapahit people choose to flee to the island of Bali and to the hinterland around Mount Bromo and Mount Semeru. The inhabitants who live in the hinterland around Mount Bromo and Mount Semeru are what we know as the Tengger tribe.

At first in the beaches, now called Pasuruan and Probolinggo, there were Hindu Waisya people who worship Brahma. Then came the Islamic religion that entered through the sea. The arrival of Islam on the island of Java in 1426M, had pressed Hindus from the coast until they finally settled in areas that are difficult to reach by migrants, namely in the Tengger area. There they formed a separate population group that is still known as the Tiang Tengger (Suyono, 2009). 
The people of Tengger now live spread around the area of Mount Bromo Tengger and Semeru. There are not too many, about 100,000 of the Javanese population of approximately 100,000,000 (Sutarto, 2006). Tengger community is not only in one district, but located in four districts, namely Pasuruan, Probolinggo, Lumajang, and Malang.

The villages of Tengger community are Ngadas, Wanatara, Jetak, and Ngadisari (Sukapura, Probolinggo), Wanakersa, Ledokombo, Pandansari (Sumber, Probolinggo), Keduwung (Puspo, Pasuruan), Ngadirejo Village, Ledok Pring (Tutur Sub-district, Pasuruan District), Ngadas Village (Poncokusumo Sub-district, Malang Regency), and Ranupani Village (Senduro Sub-district, Lumajang District) (Sutarto, 2006).

Religion espoused by the Tengger tribe is the result of Hindu Waisya or Hindu Mahayana mix with Hindu Parsi. According to R. P. Suyono, in the 16th century Brahma devotees in Tengger received the advent of fugitives from the Parsi Hindus. The Parsi Hindus are from the region around Iran. Parsi itself means Persia. In addition, the Hindu religion adopted by the Tengger tribe is a blend with traditional beliefs so that Tengger Hindu is different from Hindu in Bali. One of the different is Tengger Hindus do not recognize traditional ceremonies such as Ngaben, a Balinese cremation ceremony. While the Hindu community in Bali does not do Kasada ceremony conducted Tengger tribe. In addition, the Tengger tribe is not like Hindus in general who have temples as a place of worship. The Tenggerese worship in punden, danyang, and poten. Poten itself is a plot of land located in the Sand Sea at the foot of Mount Bromo as the place for the Kasada ceremony. Poten consists of several buildings arranged in a composition in the yard that is divided into Tri Mandala or three parts.

\section{Kasada Ceremony and Efforts to Preserve Tenggerese Culture}

Yadnya Kasada or Kasada ceremony is a Hindu religious ceremony performed by the Tengger tribe but not done by other Hindu adherents. This ceremony is very closely related to the story of the origin of Tengger society, especially about the legend of Roro Anteng and Joko Seger. After marriage, Roro Anteng and Joko Seger were eager to have children. They finally appealed to God to have 25 children. Their wish was granted on the condition that the 25th child should be offered or sacrificed to Dewa Bromo. After being grown up, Kusuma, the 25th son of Roro Anteng and Joko Seger plunged into the crater of Bromo. Then came the voice of the child asking for their parents live harmoniusly along with her brothers and sisters. Then this ceremony became the beginning of Kasada ceremony to honor the sacrifice. 
Kasada ceremony is a ritual performed once a year on the 14th and 15th full moon in the 12th month to honor Mount Brahma (Bromo) which is considered as a sacred mountain by the Tengger tribe (Figure 2). The ceremony takes place at Pura Luhur Poten located in the sand Sea, north side of the foot of Batok Mountain. While the sacrifice is located on the edge of Bromo Crater.

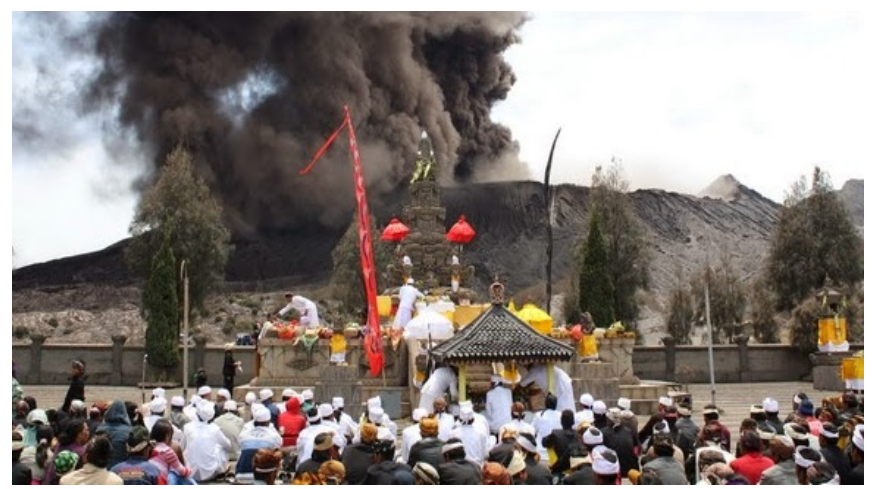

Figure 2. Kasada Ceremony

Source: explore1ndonesia.blogspot.co.id

The ceremony is also commonly called as the Kurban (sacrifice) ceremony. Five days before the Kasada ceremony, there is usually a variety of spectacles such as dances, horse races in the sea of sand, a leisurely stroll, and an exhibition. Kasada ceremony is held from midnight to early morning. Begin by walking from the front of traditional shaman house to Luhur Poten Temple. According to Prof. Dr. Simanhadi Widyaprakosa, Sesajen or offerings are called ongkek consisting of thirty kinds of fruits and cakes. This Ongkek will be thrown in the crater of Mount Bromo. Ongkek ingredients are taken from a village where for a year no one died there (Widyaprakosa, 1994) (Figure 3).

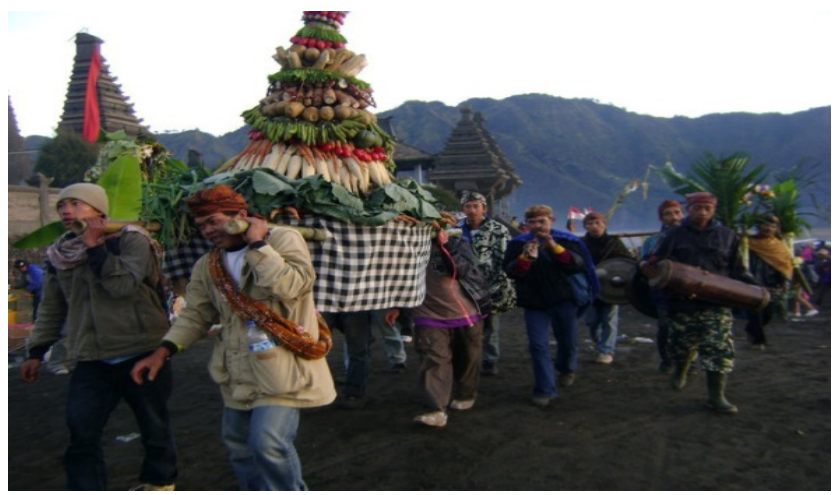

Figure 3. Ongkek

Source: belajarsecarapraktis.blogspot.co.id 
For the Tengger tribe, offerings thrown into Bromo Crater are as a form of vows (kaul) or gratitude to God for abundant livestock and agricultural products. Inside the crater there are usually many beggars or inhabitants of Tengger. They come several days before the ceremony and even deliberately set up temporary residence around Mount Bromo to get ongkek in the form of fruits, livestock, and money starting from night till noon (Figure 4).
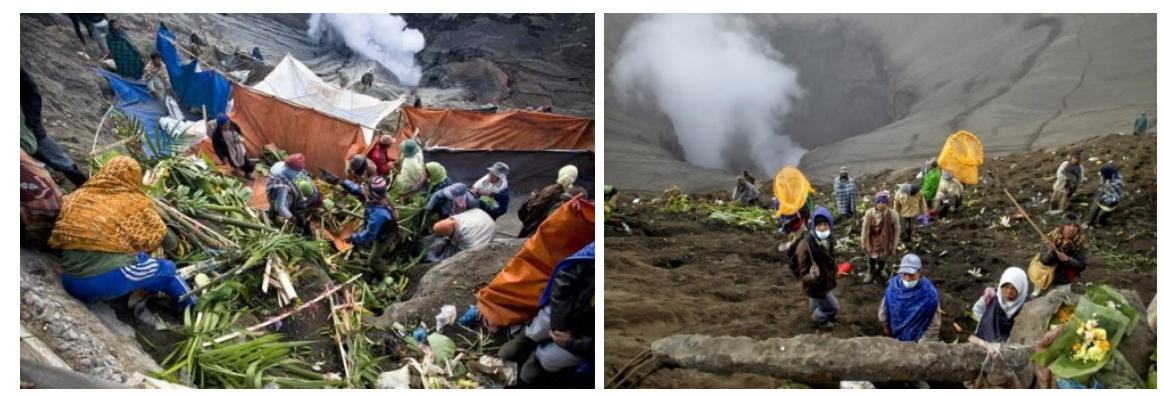

Figure 4. People Activity in Bromo Crater

Source: explore1ndonesia.blogspot.co.id

The Tengger community lives up to Titi Luri, which means following the footsteps of the ancestors or successors of the religion, beliefs and customs of their ancestors from generation to generation. Every ceremony is done without any changes, just like the ancestors did centuries ago. They believe that if there is a change in the implementation of traditional ceremonies, then disaster will come in the future. In addition, the people of Tengger are also known to be honest, obedient, and diligent work. They live a simple and peaceful life.

Tengger society condition when viewed from the economic point of view is very simple. The majority of the populations work as farmers as they realize the natural wealth owned by Bromo is so abundant. The fertile soil makes them grow crops by planting vegetables. While some of them work as civil servants, traders, laborers, and service businesses. In trade sector they open stores and restaurants. For service sector they open the lodging rental. While the transportation sector they rent jeeps and horse cars to support Bromo tourism.

From the above background, it is known that the activities of culture conducted by the Tengger tribe can be regarded as a wealth or root of national culture which continuosly by the government to be strivedly preserved. When compared with the culture of Bali, Tengger does not have a cultural village like that found in Bali. Therefore, the government has the idea to develop a cultural village located in Tengger. As a target of tourist destination, then about a few years ago, the government began to build a traditional house of Tengger. The existence of this wooden house is deliberately created as a miniature of indigenous traditional house 
of Tengger community. Preserving a culture with the concept of a village is the right choice. From that concept of village, it is expected that the culture of the Tengger tribe will be preserved countinuosly with the existence of interaction or socialization in the village to tourists who come.

\section{Tourism Potential of Tengger Region}

Besides having the potential of the Tenggerese culture, Bromo has a natural beauty and a wealth of abundant natural resources. The existence of Bromo Tengger Semeru National Park is a proof of its natural wealth. This park has an area of $50,276.3$ hectares of which there are about 137 species of birds, 22 species of mammals, and 4 species of reptilian. This area is also the only conservation place that has a sand sea area of 5250 hectares located at an altitude of 2100 masl.

Bromo Tengger Semeru Tourism is set to be one of the top priorities of tourism destinations by the government. Bromo tour is famous to foreign countries. Bromo itself becomes unique because it is a volcano that is still active until now. In 2019, the Ministry of Tourism targets the tourism sector to become the largest foreign exchange earner. The Government believes in line with the progress of Indonesian tourism in various regions will automatically improve the economy of the Tengger region as well. However, as we have seen, with the huge potential of tourism of Bromo, it does not have a significant impact on the economy of the people. As hosts in their own land, should the surrounding community can benefit from tourism to raise the economy independently so that it is not intervened by foreign investors or communities outside Bromo Tengger Semeru.

\section{Context of Architecture}

Based on the above issues, one of methods of introducing a culture is by learning and teaching. As located in tourist area, the Tengger tribe has more value for the community and tourists. Many tourists are attracted by the beauty of Mount Bromo and the culture of the Tenggerese, and hence the community benefited by it. Indigenous people of Tengger tribe can teach the culture what they usually do daily to tourists who come, and this process would be as a form of culture preservation. The formation of interaction between the citizens of Tengger tribe with tourists is what becomes an important part in the design concept. Therefore, the design focus is aimed at the concept of a tourist village, because as we know, the village is a smallest city unit. A village concept also selected to bring people closer to the tourists so as to create a good interaction with each other.

The existence of this village certainly involves economic, social, and cultural factors of the people of Tengger. So an architectural output needed is a facility that 
can accommodate a similar activity to teaching and learning as a medium of cultural recognition in the form of interaction or socialization and also suits the needs and activities of the community itself. The formation of architecture cannot be separated from these three factors (economic, social, and cultural) for becoming important integrated parts in order to provide direct benefits for the people of Tengger tribe in particular.

\section{Proposed Type of Design Object}

The development of tourism by involving the role of culture village is basically the application of the concept of tourism development policy of populist dimension. This community-based development is a reaction to the policy of conglomeration development that has been more pro-ownership of capital that generally does not come from members of the local community. Community-based development focuses on improving people's economy and community empowerment. Rural development thinkers and practitioners have long recognized that conglomeration development often harms local people. The community as the rightful owner of local resources often experience marginalization so that the quality of life is decreased. On that basis some other experts emphasize the importance of development from below, development as social learning, and development must start from the bottom (buttom up).

According to Korten (Suryawan and Pujaastawa, 2009), development with this reversed paradigm demands local community participation in various stages of development, so that the management of development is actually done by those living and affected most life by the development, or known as community based resource management or community management.

From the above explanation, the concept proposed is a cultural tourism village by making homestay homes. With the existence of this cultural tourism village, tourists can live side by side, learn and see firsthand the original culture of Tengger tribe. This village will become one of the Tengger people who still run their ancestral traditions so that the architecture that appears not only in the form of occupancy but also other architectures that support the culture and habits of the community. Homestay, in this case, is that one of the residents occupancy rooms rented out as tourist accommodation that cannot be separated from the original architectural values Tengger. In addition, the homestay can raise the economy of citizens independently.

The development of this cultural tourism village in addition to the preservation of culture is also directed to improve the dignity and prestige, and strengthen the identity of the Tengger community, improve the welfare of Tengger society equally and sustainably. This is also in line with the development of Bromo tourism aimed 
at developing and utilizing all the potential of regional tourism, developing tourist attraction, and increasing community participation.

\section{Theory of Community-Based Tourism}

Community-based tourism is based on a community-based resource management theory. According to David Korten (Moeljarto, 1993), the main features of this theory are: (1) Initiatives and decision-making processes to meet the needs of society must be placed on the community itself. (2) The main focus is on enhancing people's ability to manage and mobilize resources to meet their needs. (3) Tolerance local variations and hence this theory is highly flexible to adapt to local conditions. (4) In carrying out the development, emphasizing on the social learning in which there is interaction between community members from the planning process until the project evaluation. (5) The process of networking between bureaucrats and nongovernmental organizations, independent independent organizational units, is an integral part of this approach both to improve their ability to identify and manage resources and to maintain a balance between vertical and horizontal structures. This networking process is expectedly able to form symbiosis between development structures at the local level.

According to Korten (Suryawan and Pujaastawa, 2009) there are three basic reasons why community-based management is so important as a basic developmental approach. First, the presence of local variety that cannot be applied equally. Different regional situations require different management systems and local communities who best understand the local situation. Secondly, the existence of local resources that have traditionally been managed by the local people from generation to generation. The experience of managing local resources that have been passed down from generation to generation generally leads to an accumulation of knowledge about management. This management takeover will create a sense of community and society's antipathy towards the development project. Third, local accountability means that the management done by the local community is usually more responsible because of the various things they do to the resources will directly affect their lives. Outer management often does not contain moral closeness to the local community, so it does not feel to have a high moral responsibility. In the context of tourism, community-based development has recently become very important.

According to Kit (Dewi, 2013) there are 4 community-based tourism objectives: (1) Community-based tourism should contribute to improving and or rehabiliting nature conservation or cultural resources, including biodiversity. (2) Community-based tourism should contribute to local economic development so as to increase income and profit for the community. (3) Community-based tourism should 
involve the participation of local communities. (4) Community-based tourism has a responsibility to tourists to provide products that care about the natural environment, social and cultural. The above-mentioned community-based tourism theory is deemed relevant to explain the problem, which is about the form of tourism development based on the Tenggerese culture village that is managed by the community itself.

\section{THEORY/ RESEARCH METHODS}

\section{Design Method}

The design methods presented by Donna P. Duerk are Architectural Programming and Rationalist Approaches method: Design Researches and Precipatory Design. Method of Architectural Programming is chosen to help shape the concept of architectural design that can answer issues raised and in accordance with the purpose or achievement of the construction of this architectural object. Method Design Researches are used to help collect data on the standards or information needed in relation to building technology and materials needed in the process of designing, both from the archipelago architecture approach and the green architecture.

\section{Architectural Programming}

The design process method used in designing this object is the Architectural Programming method of (Duerk, 1993). "Architectural programming is the process of managing information so that the right kind of information is available at the right stage of the design process and the best possible decisions can be made in shaping the outcome of the building design". There are two main parts of concern to this method, namely the analysis of the existing state and the projection of the future state. Analysis of the existing state is a design context that covers things like land analysis, user profiles, codes, constraints, and climate. Projection of the future state is a set of criteria that must be met by a design to achieve success including mission, goals, concepts, and performance requirements.

Architectural programming is one of the methods in architectural design. Design issues are formulated at the beginning systematically with the intention of directing the design results to the desired destination. Architectural programming is needed primarily to minimize the risk of error and to streamline the design process. Architectural programming evolved as a scientific, systematic, and analytical approach in the realm of architectural design. One of the architectural programming models developed by Duerk is issue-based architectural 
programming. Duerk states, a design must start with a mission statement, namely the reason the work needs to be done. Then sort out the issues according to specific issues, which are further downgraded into several objectives, design criteria, and design concepts (Figure 5).

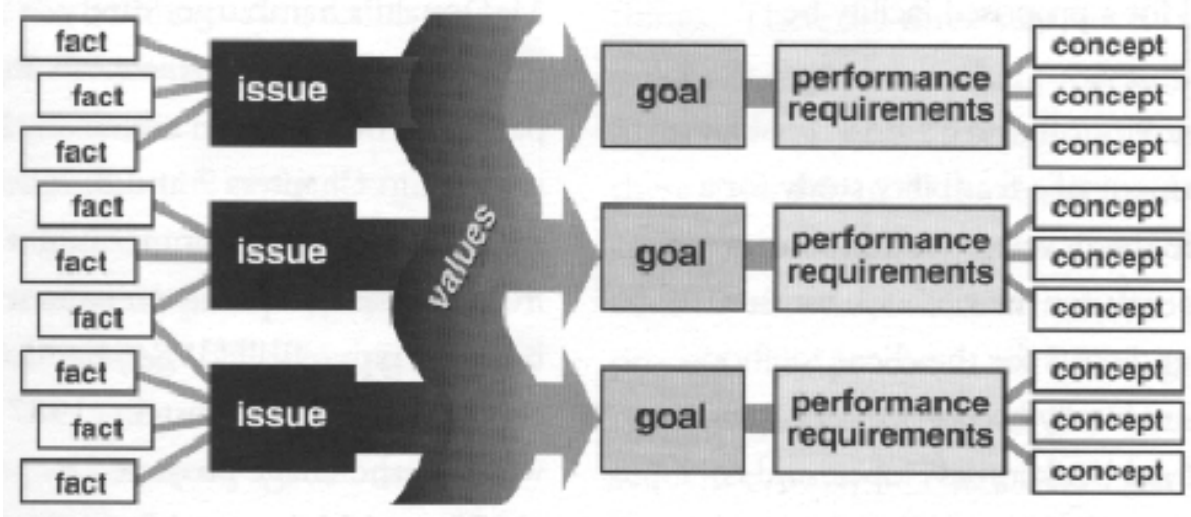

Figure 5. Schematic Design Programming Source: arch.ttu.edu

\section{Rationalist Approaches: Design Research}

The next design method is taken from Basic Design Methods (Jormakka, 2008). This method is a design method by analyzing, from issues to the responses presented. It takes parameters to then be reanalyzed and evaluated to produce the best architectural design solutions (Table 1).

Table 1. Architectural Programming Table

\begin{tabular}{|c|c|c|c|c|c|}
\hline Fact & Issue & Problem & Goal & Criteria & Concept \\
\hline $\begin{array}{l}\text { Tenggerese } \\
\text { culture only } \\
\text { exist in the } \\
\text { area around } \\
\text { Mount } \\
\text { Bromo and } \\
\text { Semeru }\end{array}$ & Culture & $\begin{array}{l}\text { - Tenggerese } \\
\text { culture is a } \\
\text { culture that } \\
\text { can be said } \\
\text { to be } \\
\text { almost } \\
\text { extinct. } \\
\text { - The } \\
\text { absence of } \\
\text { facilities as } \\
\text { a medium } \\
\text { of cultural } \\
\text { preservatio } \\
\text { n by means }\end{array}$ & $\begin{array}{l}\text { Forming the } \\
\text { village as a } \\
\text { medium in } \\
\text { preserving } \\
\text { Tenggerese } \\
\text { culture to } \\
\text { tourists with } \\
\text { social } \\
\text { interaction, } \\
\text { that is } \\
\text { teaching, } \\
\text { seeing, and } \\
\text { experiencing } \\
\text { directly }\end{array}$ & $\begin{array}{l}\text { - Arrangement } \\
\text { of the village } \\
\text { by adapting } \\
\text { the cultural } \\
\text { values of } \\
\text { Pura Luhur } \\
\text { Poten }\end{array}$ & $\begin{array}{l}\text { - Implement the } \\
\text { concept of Tri } \\
\text { Mandala in the } \\
\text { arrangement of } \\
\text { the village, } \\
\text { which are the } \\
\text { Main Mandala, } \\
\text { Madya Mandala, } \\
\text { and Nista } \\
\text { Mandala }\end{array}$ \\
\hline
\end{tabular}




\begin{tabular}{|c|c|c|c|c|c|}
\hline Fact & Issue & Problem & Goal & Criteria & Concept \\
\hline & & $\begin{array}{l}\text { of social } \\
\text { interaction }\end{array}$ & & & \\
\hline $\begin{array}{l}\text { The } \\
\text { government } \\
\text { makes } \\
\text { Bromo } \\
\text { Tengger } \\
\text { Semeru as } \\
\text { one of the } \\
\text { priority } \\
\text { tourism } \\
\text { destinations }\end{array}$ & Tourism & $\begin{array}{l}\text { The people } \\
\text { of Tengger } \\
\text { tribe have } \\
\text { not } \\
\text { maximized } \\
\text { in utilizing } \\
\text { tourism } \\
\text { sector in } \\
\text { economic } \\
\text { activity }\end{array}$ & $\begin{array}{l}\text { - Increasing } \\
\text { the } \\
\text { economy of } \\
\text { Tenggerese } \\
\text { people } \\
\text { independent } \\
\text { ly by } \\
\text { establishing } \\
\text { a homestay } \\
\text { that } \\
\text { supports the } \\
\text { tourism } \\
\text { sector } \\
\text { - Homestay } \\
\text { with } \\
\text { Tengger } \\
\text { architectura } \\
1 \text { design and } \\
\text { green } \\
\text { architecture }\end{array}$ & $\begin{array}{l}\text { - Homestay } \\
\text { with room } \\
\text { zonification } \\
\text { arrangement } \\
\text { with Luhur } \\
\text { Poten } \\
\text { Temple } \\
\text { concept } \\
\text { - Maximize } \\
\text { natural } \\
\text { exposure } \\
\text { and lighting } \\
\text { to minimize } \\
\text { energy } \\
\text { - Design } \\
\text { space } \\
\text { according to } \\
\text { user needs } \\
\text { - Minimize } \\
\text { new } \\
\text { resources in } \\
\text { development } \\
\text { - Concern } \\
\text { more to the } \\
\text { initial } \\
\text { condition of } \\
\text { the land }\end{array}$ & $\begin{array}{l}\text { - Implement the } \\
\text { concept of Tri } \\
\text { Mandala in } \\
\text { zoning } \\
\text { arrangement of } \\
\text { homestay room } \\
\text { - Uses transparent } \\
\text { roof for sunlight } \\
\text { to enter } \\
\text { - Using cross } \\
\text { ventilation by } \\
\text { putting a window } \\
\text { in each room } \\
\text { - The rooms and } \\
\text { layout of the } \\
\text { homestay are } \\
\text { adapted to the } \\
\text { Tenggerese social } \\
\text { culture (Sanggar, } \\
\text { Patamon, etc.) } \\
\text { - The material used } \\
\text { is the wood } \\
\text { material as the } \\
\text { main material and } \\
\text { the existing } \\
\text { material of the } \\
\text { building is } \\
\text { maintained (in the } \\
\text { restored and } \\
\text { revitalized } \\
\text { building) } \\
\text { - Maintaining the } \\
\text { land contour with } \\
\text { the concept of } \\
\text { terracing }\end{array}$ \\
\hline
\end{tabular}

\section{Analysis}

In the process of analysis, from in-depth interviews conducted on some tourists, found the fact that: (1) The majority of tourists who attend Bromo area have a purpose to enjoy the beautiful view of Mount Bromo, that is when the sun rises. (2) Tourists do not pay much attention to local architecture because the main purpose is to enjoy its natural beauty and its cool and fresh air. The opinion of tourists is supported by the fact that the condition of residential houses or 
settlements there has been modified from traditional houses of indigenous Tengger tribe that became less attractive due to the same appearance with ordinary buildings. (3) Tourists want a decent homestay model house as the quality of existing homestay is not sufficient.

Therefore, conservation methods are needed to solve these problems so that existing buildings can be restored to their original form. Thus, the initial goal to raise Tenggerese culture can also be reflected in terms of architecture.

\section{Building Conservation}

Conservation is generally defined as preservation. However, the term is commonly used conservation architects refer to the Charter of the International Council of Monuments and Site (ICOMOS) in 1981, i.e: Charter for the Conservation of Places of Cultural Significance, Burra, Australia. This charter is better known as Burra Charter.

Conservation activities may include: (a) Preservation. (b) Restoration. (c) Replication. (d) Reconstruction. (e) Revitalization or use for new functions of a past asset. (f) Rehabilitation. These activities depend on the conditions, issues, and possibilities that can be developed in further maintenance efforts.From these explanations, the old building functions are used for new relevant activities as well as allowing to change old activities to new ones without having to eliminate them.

In the design of this village, not all buildings are conserved, but there are parts that are developed. This is based on the survey results that the main thing attract tourists to visit the area is the view of Mount Bromo. But on the other hand, to maintain the local architecture, then some buildings which are still in feasible condition will be restored. The rest will be revitalized and redesigned in accordance with the wishes of the majority of tourists. So that will appear two design concepts on this village, the concept of conservation (restoration and revitalization) and of development. Also, in this method, facts that will become the material of space order analysis of the village and house are collected. These facts then become the reference in designing the followings:

\section{Composition of the Settlement Element}

Identifying the value of local wisdom in the settlement can be seen from certain custom rules or provisions that govern the orientation of laying the elements of settlement. The concept of direction that developed and became a hereditary belief of Tenggerese society has a philosophical meaning and is symbolized by certain color elements. The meaning of the concept of direction is then interpreted in the ritual Pujan Mubeng (Nrundhung) ceremony which aims to request for safety for the 
village and clean the village from disruption and disaster. The form of applying the philosophical meaning contained in the concept of direction is based on the customs and beliefs of Tengger tribe society is in the form of various colors of offerings (red, white, yellow, black) which has philosophical meaning symbolizing the four corners of the village.

In Ngadisari village there is a customary rule application of which becomes the basis of the concept of direction in placing the settlement elements, such as: (1) The grave consists of sacred graves and ordinary graves. The provision of laying the sacred grave is to the north of the village and away from the residential location of the inhabitants. The belief amongst Tenggerese related to the laying of the tomb is preferably outside the residential area and placed in the north. It has remained in the same place with the fixed extent of land that ought not to be increased or decreased since long time ago. (2) Temple (Pura) as a place of worshiping god is placed in a sacred place in the middle of the settlement, where there are most sanggar pamujan in the vicinity. The location of Dhang Kahyangan Kerti Jaya Buana Temple in Ngadisari Village is in the north-east of the residential area. The philosophical meaning contained in the provisions of the laying of the temple in the East is because it is facing towards the sun. As a sacred place, the temple is placed on the highest contour of the land. (3) Padhanyangan (dhanyang) is a place sacred by the people of Tengger Desa Ngadisari. The location of padhanyangan (dhanyang) is to the South of the village and is at one orientation with a sacred tomb (leading to Mount Bromo). (4) Residential building (micro) is divided into several spaces with the provisions of laying each space, e.g: (a) Sanggar pamujan (shrine) placed in front of the house must face to the East or South, should not face West and North. Sanggar is a place of offerings and storage of heritage. It also serves for a place of worship at the ceremony of death. (b) Patamon (living room) is placed on the front of the house. (c) Paturon (bedroom) should be on the right side of the door. (d) Pagenen (kitchen) and pedaringan (storage space) are placed behind the patamon and may be combined. (e) Pakiwan (bathroom) should be at the back of the house. (f) Pekayon (a place to store wood) is an additional space, placed at the back of the house. There is also a customary provision that states a married child should not build a house on the right of his parents' home. (5) The fields or fields used for agriculture are located in the South, North and East of the village. (6) Mount Bromo which is located in the south is believed to be the axis (pancer) of spiritual activity throughout the Tengger people. There is a sacred axis that leads to Mount Bromo (South) that connects between the sacred tomb and padhanyangan (dhanyang).

Tengger traditional house stands with no level, not a house on stilts, standing straight parallel to the ground. The structure is composed of boards or wooden rods. The roof is high so it looks very steep. In the yard of the house there are no tall tree 
plants. Tengger house width 4-8meter, 15-20meter long. Traditional houses of the Tengger tribe has only one or two windows (Suyono, 2009).

In the process of analysis, from in-depth interviews conducted on some tourists, found the fact that: (1) The majority of tourists who attend Bromo area have a purpose to enjoy the beautiful view of Mount Bromo, that is when the sun rises. (2) Tourists do not pay much attention to local architecture because the main purpose is to enjoy its natural beauty and its cool and fresh air. The opinion of tourists is supported by the fact that the condition of residential houses or settlements there has been modified from traditional houses of indigenous Tengger tribe that became less attractive due to the same appearance with ordinary buildings. (3) Tourists want a decent homestay model house as the quality (Figure 6).

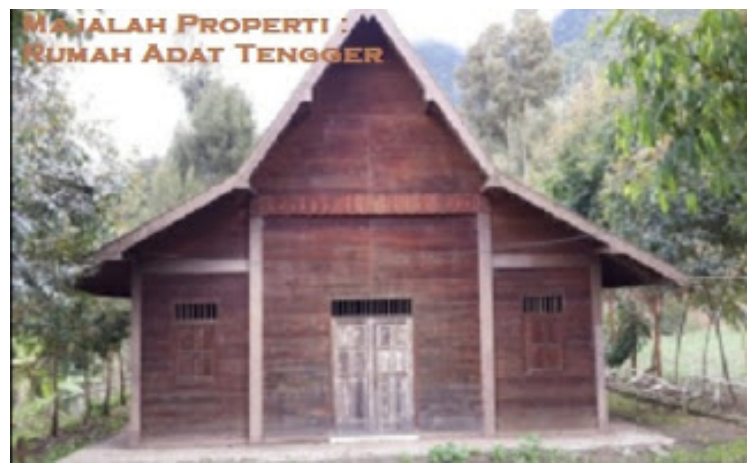

Figure 6. Traditional House of Tengger Source: rumahperumahan.com

In the traditional house of Tengger, materials once used were wood and bamboo. However as influenced by modern architecture, Tenggerese now use a tile or zinc for their roof instead of bamboo. The traditional characteristic of Tenggerese house that remains is the front part of the house, with seats which is more like a divan, placed in front of the house.

\section{Adaptation of Dwelling to Climate}

One form of applying the value of local wisdom is the adaptation of the dwelling to the climate. The construction of traditional houses of Tengger Ngadisari village has the ability to adapt to the local climate. The climate adaptation factor has resulted in several changes and developments in the use of building materials on traditional houses of Tengger Desa Ngadisari community from time to time. The appearance of traditional houses of Tengger Desa Ngadisari can be explained based on the facade of the building and the building fixtures such as roof, wall, pole, door, and window. Existing condition of building of traditional house of Tengger Tribe of Ngadisari Village is as follows: (1) The pyramid-shaped roof resembles a triangular vertical pit 
with a slope side of $\pm 45^{\circ}$, made of zinc. (2) Wall in the form of wall or half wall. The wall is made of brick while the meaning of a half wall is a blend of walls with wooden planks. (3) The door is made of wood. (4) Window made of wooden frame and glass.

The characteristic of adaptation of Tengger Desa Ngadisari traditional house to local climate can be explained based on the function of some components found in residential building construction and surrounding environment. The change in the use of roof materials on traditional houses of the Tengger Tribe Ngadisari Village is caused by adaptation factor to the local climate. In about the 1950's the roof used materials from zinc, but later in the 1970s it was replaced by using tile. But it turns out the roofing house using tiles actually causes the temperature inside the house becomes colder. Therefore, since the 1980s the roof on the traditional house Tengger Village Ngadisari replaced again by using materials from zinc which was more appropriate if applied to cold climates such as in Ngadisari Village. From the changes in the use of materials for the roof can be identified form the value of local wisdom that is through the trial and error (trial and error), then obtained the most appropriate and adaptive results if applied. With a triangular upright roof reduces the risk of collapse during volcanic ash rain.

\section{Luhur Poten Temple}

Originally this temle is the residence of Ida Sang Hyang Widhi Washa. Now, this temple is used as a place of worship by Tengger Hindus. Luhur Poten Temple becomes a place to worship God Brahma. In the temple there are three areas that each of them has different functions: (1) Utama Mandala, the place of worship and prayer. (2) Madya Mandala, the place of preparation and accompaniment of the prayer ceremony. (3) Nista Mandala is the transition place between the entrance and Utama Mandala. Like other temples, Luhur Poten Temple is built towards the West with the shrine (Utama Mandala) facing towards the East following the direction of the coming of the sun (Figure 7 and 8).

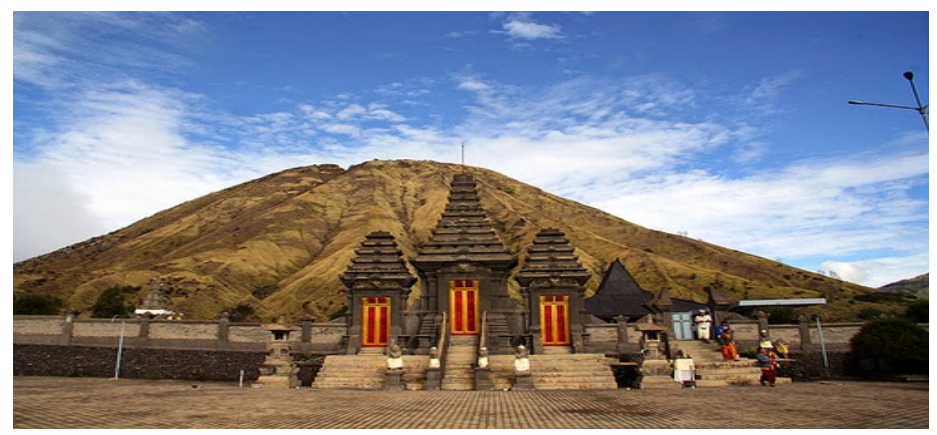

Figure 7. Luhur Poten Temple

Source: newduniatravel.blogspot.co.id 


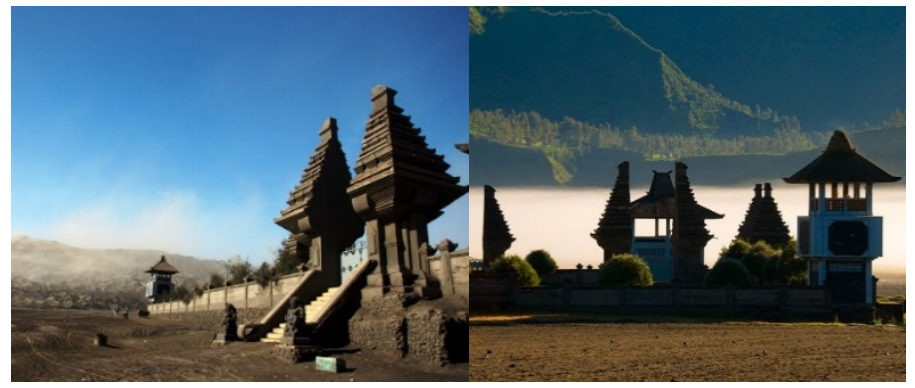

Figure 8. Luhur Poten Temple

Source: belajarsecarapraktis.co.id

\section{Activity Phenomenon}

The phenomenon of activity explains activities that occur predominantly in a case, in this case means the main activity of the Tengger Tribe in Cemoro Lawang Hamlet, Ngadisari Village. By knowing the phenomenon of existing activities, hopefully this activity will be adjusted to the issues raised so that it can be regarded as a problem to be solved with activities that seek to be created through the proposed object.

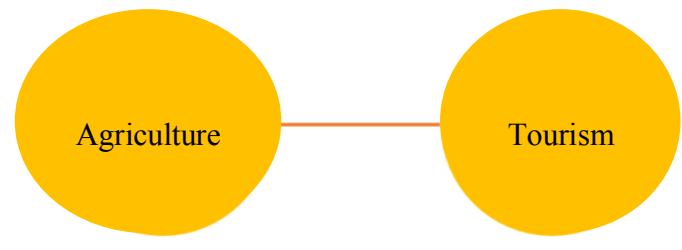

Figure 9. Activity Relations in Agriculture and Tourism Sector

The majority of the population in selected location areas works in the agricultural sector and does not utilize the existing tourism sector. Therefore, in accordance with the objectives, it is necessary to have a relationship between the agricultural sector with the tourism sector so as to improve the economy of the population with the presence of new activities (Figure 9).

\section{Village Activity}

In village activity, it is determined that the user is an external (public) actor which means individual or group actors directly related to the activities of a space, but not directly related to the ownership or management of the space. Activities that occur within the scope of the village are likely as a place of deliberation among villagers, a place to hold events or performing arts and exhibitions. Usually five days before the Kurban ceremony or Kasada ceremony, people hold various spectacle such as 
dances, horse races in the sea of sand, relax walk, and the exhibition. In addition, the dominant activity is farming as the majority of the inhabitants are farmers. They daily go to the fields, planting seedlings, treating, to harvesting vegetable.

\section{Homestay Activity}

In the activity in the homestay, determined by user as an individual or group actors directly related to the activities, ownership and management of a space. This group is also legally entitled to use the room. These internal (private) actors can be divided upon heirarchies or levels of privacy, from a low to high level of privacy. In this object, homeowners or homestays are in a high hierarchy, while guests or travelers who rent a room have a lower hierarchy. Activitiy that exist on this objects is like any residential in general. Residents can perform various activities such as praying, eating, sleeping, bathing, etc.

Homestay facility with the number of residents is determined six people, consisting of four permanent residents, namely father, mother, and two children and two tourists as temporary residents. Especially for the business space may vary, depending on what group they belong to. In this case it is categorized into five kinds of business groups, i.e. Handicrafts group makes scarves, gloves, and hats which then sold to tourists. A souvenirs group sells daily necessities such as food, souvenirs either in the form of food or Bromo typical goods. There are also business groups that open a restaurant or shop. Last is the business group in the field of transportation, so specifically for this group, a garage is their main needs (Figure 10).

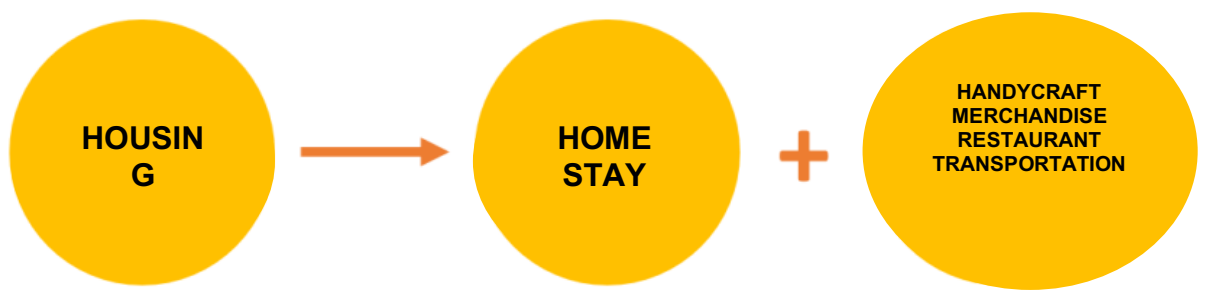

Figure 10. Functionality Change Diagram

The majority of the population in selected location areas works in the agricultural sector and does not utilize the existing tourism sector. Therefore, in accordance with the objectives, it is necessary to have a relationship between the agricultural sector with the tourism sector so as to improve the economy of the population with the presence of new activities. 


\section{Zonification}

Zonification on the spatial pattern of the village is divided based on the concept of Tri Mandala value and conservation area. Both will be linked so as to have an order that the restored area is the Utama Mandala, the revitalized area is Madya Mandala, while the redesigned area becomes the Nista Mandala area. This division is based on the level of the building authenticity on the site.

Meanwhile the zonification on the homestay itself is divided into vertically and horizontally. Zone division of space vertically is meant in order that both homeowner and guest can have their own privacy. While the horizontal division zone includes the concept of Tri Mandala, i.e. from the front to the back of the house has the order of Main Mandala, Madya Mandala, and Nista Mandala. Living room, dining room, and kitchen can be used as a gathering room or can be used as a shop by the homeowner (Figure 11).

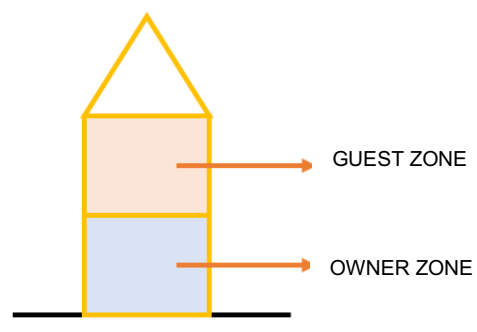

(a)

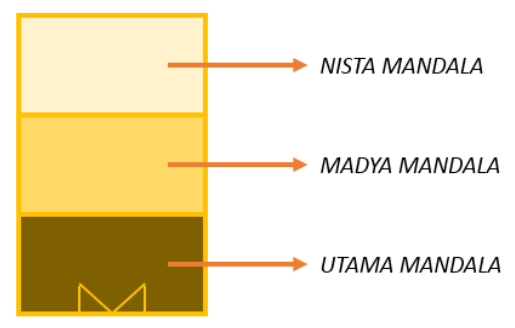

(b)

Figure 11. (a) Vertical Zonification (b) Horizontal Zonification

\section{RESULTS \& DISCUSSION}

\section{Design Concept}

The concept of design in Kampung Wisata Budaya Tengger applies the same concept to the temple used by Tengger tribe to pray, that is Luhur Poten Temple. The design concept of Tengger Cultural Tourism Village, in macro, will use Tri Mandala pattern. The arrangement of the village site plan will be divided into three parts, namely the utama, madya, and nista. The grouping of this area is not intended for the classification of the houses but the grouping of the whole village layout because in the Tengger tribe does not recognize the caste system so that all are considered to have the same degree. There is no distinction of social or economic status (Figure 12). 


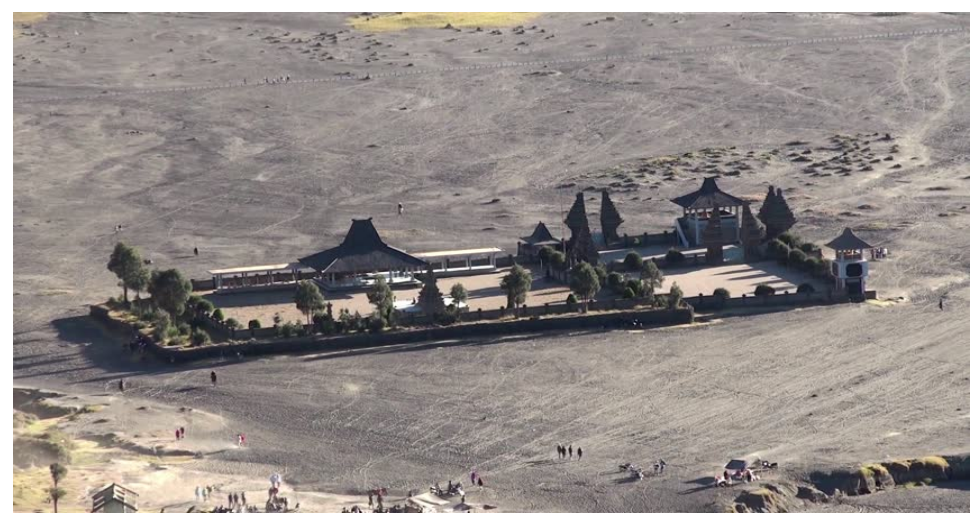

Figure 12. Luhur Poten Temple

Source: shutterstock.com

Besides, in general, the village area is also divided into two groups or zonification, ie conservation areas and development areas. In the conservation area is further divided into two parts, namely the area of restoration and revitalization area. The existence of conservation area aims to maintain local architecture in Tengger region, while the area of revitalization and development is an area that is intended to answer the needs of economic improvement of society and the needs of tourists who are dominated by people who want to enjoy the view of Mount Bromo.

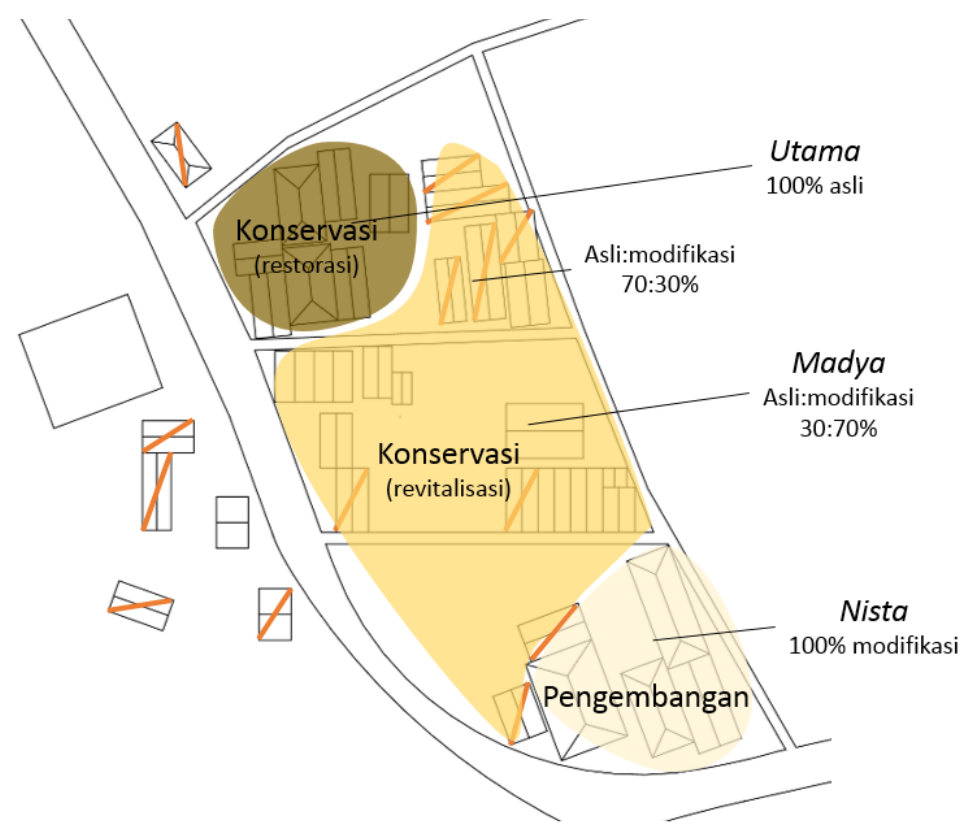

Figure 13. Macro Design Concept 
The Utama Mandala area is a conservation-restoration area due to in that area a group of buildings can be said still worth to be maintained. So, it requires restoration or returning the building back to their initial form. This will be a group of buildings with the authenticity of the Tengger traditional house. Furthermore, Madya Mandala is a conservation-revitalization area where existing buildings will maintain its function but will get physical restoration because of the condition of the building that is less feasible. In this area, 30\% original and $70 \%$ modification. This area also has open space or communal space that is located in the middle area and used as the center of social activities in the village, ie adopting the concept of laying a temple in which has to be placed in the center. Therefore, in Madya Mandala there is sub-classification that is Utama ning Madya, Madya ning Madya, and Nista ning Madya. In the Nista Mandala is a total-designed building area or development area and farm or field area. Communal spaces and other open spaces such as farms or fields are designed as well in order to create an interaction between residents and tourists. This productive area is designed to be used for farming without reducing its aesthetic value (Figure 13).

Phase 1 is in the conservation-restoration area. In this area existing buildings of Tengger society are still in decent conditions yet some parts have changed from its traditional value, so the physical form of the building is restored back to their initial physical form. The goal is to preserve local architecture and in accordance with the issues of cultural preservation on architecture of Tenggerese House. In phase 1, the building function can be a regular homestay (Figure 14).

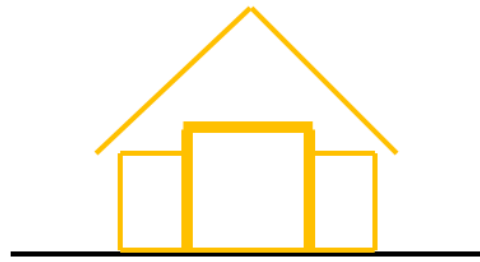

Decent Tengger Existing Building

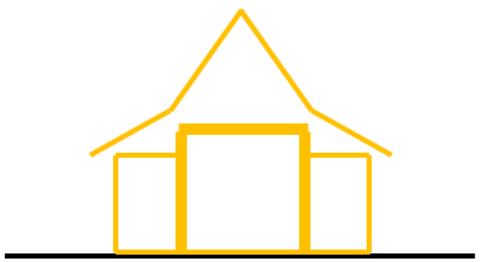

Tengger Original House

Figure 14. Conservation-Restoration

Phase 2 is in the conservation-revitalization area. In this area contains Tenggerese existing buildings with the condition that is less feasible. Revitalization will be divided into two types, namely with "fixed function, changed shape" and "changed function, fixed shape". In this case, the shape of the building will be changed with a fixed function in order to be able to increase the value of the building and economic value in terms of attracting tourists. In this area is divided into two, namely with the architectural percentage between the original to the 
modification with 70:30 and of between the original to the modification with 30:70. The goal is to create a transition architectural design model and still looked to have unity in one region. In phase 2 , the function of the building can be a homestay with a more decent concept and in the form of shops and restaurants (Figure 15).

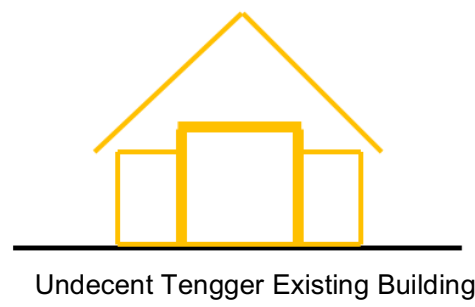

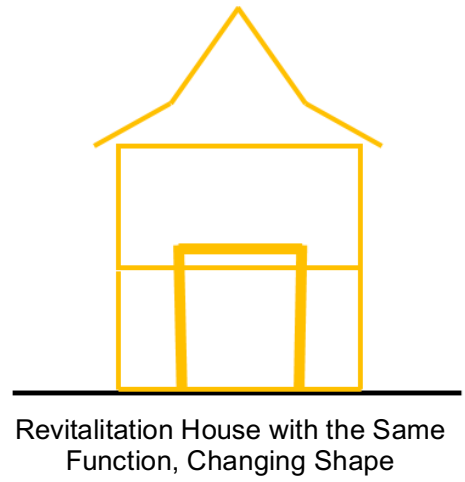

Figure 15. Conservation-Revitalization

Phase 3 is in the development area. In this area, existing buildings can be fully designed so that it can create a completely new shape, but still cannot be separated from the surrounding buildings. Just like phase 2, the function of the building can be a homestay with a more decent concept and in the form of shops and restaurants but can give different nuance (Figure 16).
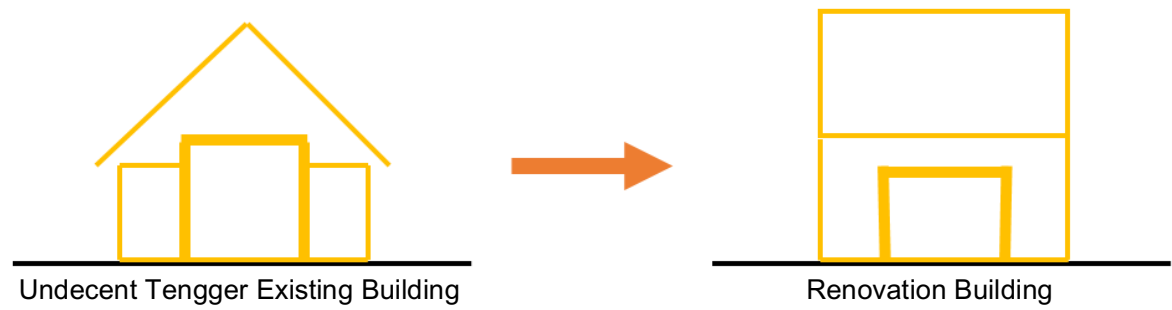

Figure 16. Development

The homestay mass arrangement has an irregular pattern. These houses are arranged in clusters and close to each other. Between one house with another house is only separated by narrow pedestrian path. The concept of this adjacent house will still be applied in the design but with a more neat pattern. Such a mass arrangement of buildings works to deal with the extreme wind and cold weather. With the pattern of mass arrangement, the wind cannot be crashed and will soon be blocked by the assembled houses (Figure 17). 


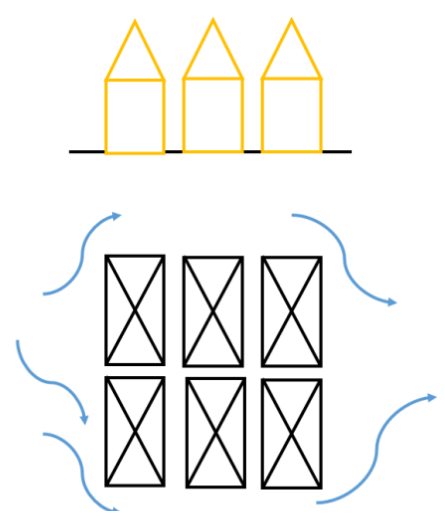

Figure 17. Windflow in the Settlement

Composition is an arrangement of activities designed and planned in accordance with technical and non-technical considerations. Composition has always something to do with the concept of floor plans or plans on the building. The space composition in this homestay follows a predetermined zonification, that is based on vertical and horizontal divisions that reflect the Tri Mandala concept (Figure 18).

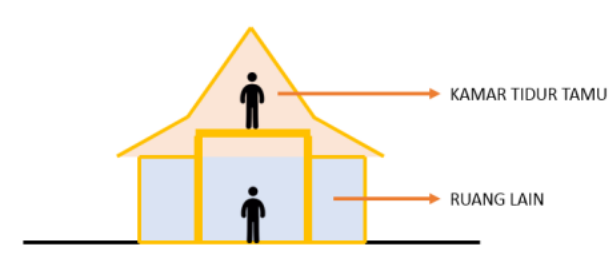

(a)

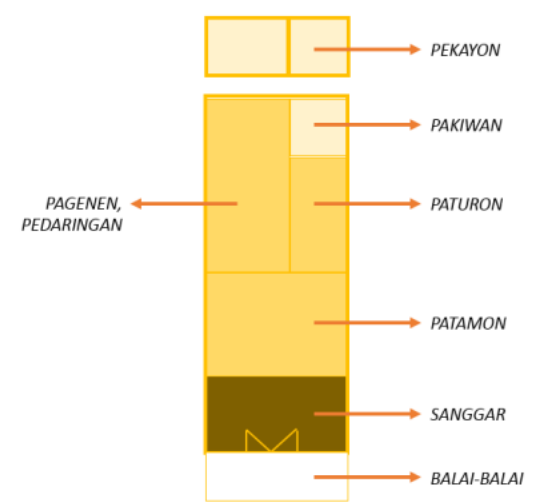

(b)

Figure 18. (a) Vertical Composition (b) Horizontal Composition 


\section{CONCLUSION}

The conclusions of this discussion are:

a. Settlement Composition, composition of space in the house and environment in the Tengger tribe have similarities with the culture of Balinese Hindu society (Tri Mandala, Sanga Mandala, Tri Hita Karana).

b. On the existing conditions, where the place of praying Tengger society placed on the side of the road. does not lead to Bromo mountain. In contrast to the Hindu population in Bali, Agung mountain became the center of orientation in worship.

c. Tengger community activities related to hereditary cultures, can be an interesting commodity as a tourist attraction.

d. New Design of settlement of Tengger society, can be applied by applying Tri Hita Karana / Sangamandala order pattern, so that it can preserve the existing culture.

\section{REFERENCES}

Al Anshori, Junaedi. 2010. Sejarah Nasional Indonesia: Masa Prasejarah. Sampai Masa Proklamasi Kemerdekaan. Jakarta: PT Mitra Aksara.

A.M.W. Panarka; Vidyandika Moeljarto (1996). Pemberdayaan (Empowerment). Jakarta: CSIS

Dewi, M. H. (2013). Pengembangan Desa Wisata Berbasis Partisipasi Masyarakat Lokal Di Desa Wisata Jatiluwih Tabanan, Kawistara: Bali

Duerk, Donna P (1993). Architectural Programming: Information Management for Design. Publisher: Wiley; 1 edition ( ISBN-10: 0471284688; ISBN-13: 9780471284680).

ICOMOS CHARTERS (1981). International Charter for the Conservation and Restoration of Monuments and Sites. Venice Charter: Venice.

Jormakka, K (2008). Basics Design Methods. Bikhauser.

Koentjaraningrat (1974). Pengantar Antropologi. Jakarta : Aksara baru.

Sutarto (2006). Sekilas tentang Masyarakat Tengger. Reserach Gate.

Suryawan, Wiranatha, I. B. G. Pujaastawa (2009). Analisa pasar wisatawan Nusantara. Bali: Dinas Pariwisata Provinsi Bali.

Suyono, RP. (2009). Mistisme Suku Tengger. Yogyakarta: PT LKIS Pelangi Aksara.

Turmudi, Endang (2008) Pendidikan Islam setelah Satu Abad Kebangkitan Nasional. Yogyakarta: Ilmu Ilmu Sosial Indonesia XXXIV.

Widyaprakosa, Simanhadi (1994). Masyarakat Tengger : Latar Belakang Daerah Taman Nasional Bromo. Yogyakarta : Kanisius. MLA Citation. 
Suryawan \& Permatasari : NATIVE CHARACTERISTIC OF INDIGENOUS INDONESIAN CULTURE AS REFERENCE IN RE-DESIGNING TOURISM AREA

This page is intentionally blank 